Junichi Toyota

$811.111 ' 36$

Graduate School of Literature

doi 10.18485/analiff.2015.27.2.17

and Human Sciences

Osaka City University

Faculty of Philology

University of Belgrade

\title{
INTENTION IN FUTURITY: A HISTORICAL OBSERVATION OF THE FUTURE TENSE IN ENGLISH ${ }^{1}$
}

This paper analyses various expressions denoting futurity in English from a historical perspective. It is commonly known that English lacks the future tense, but futurity is denoted by deontic or epistemic modality in shall and will, respectively. According to a general pattern in grammaticalisation, auxiliaries are believed to be one of the stages before a lexical item becoming an affix. In this process, a loss of semantic content, i.e. semantic bleaching, takes place. Previously, this process, particularly the loss of intentionality, is believed to have happened when the auxiliary is formed, but it is better to consider that it is still retained, and in a later process of cliticisation (i.e. the production of -' $l l$ ), which is currently happening in English, this semantic bleaching is taking place based on a strong co-relation between the appearance of clitic and first person pronouns, a piece of evidence taken from corpora. Based on the current state of grammaticalisation, it is possible to predict what is likely to happen in the tense system in English.

Key words: future tense; auxiliary; clitic; grammaticalisation; intentionality

\section{Introduction}

This paper analyses an issue of the future tense in English from a historical perspective. A number of grammarians have argued that the future tense in English is expressed by modal auxiliaries such as will and there is no specific future tense. We do not attempt to contradict this argument, but when it comes to recent changes in English, it may be possible to postulate a hint of a future tense, especially in the clitic form of auxiliaries

1 Abbreviations used in this work are: GEN = genitive; NEG = negative; PRT = participle; PST $=$ past. 
will and shall, based on a general principle of grammaticalisation chain. It is assumed in this paper that grammatical structures are at flux, and what we may consider under a synchronic analysis may be at a cutting edge of radical changes. Concerning the modal auxiliaries for expressing futurity, Present-day English has a lexical form and a clitic form, and such variations in form can be an indicator for possible new invention.

This paper starts with a brief review of expressions referring to futurity in English in order to state the basic view concerning futurity in English in this paper. Then a history of expressions normally discussed under the future tense in prescriptive grammar is provided in details. Following this, grammaticalisation paths are described in relation to auxiliaries in English, particularly focusing on two stages, i.e. auxiliary and clitic. Finally, a relationship between clitic and first person pronouns is analysed in terms of intentionality, based on data taken from corpora. The data are taken from two corpora, London-Lund corpus (LL corpus, spoken) and London-Oslo-Bergen corpus (LOB corpus, written), covering both spoken and written registers.

\section{Future tense in English}

The tense system in English can be a matter of debate concerning the future tense, but it has been commonly considered as the past v. non-past type, without a future tense. This type of debate is caused by the presence of auxiliaries such as will and shall, as in I will go there tomorrow. The futurity expressed with the auxiliary willis often mistaken for future tense, but it is more closely associated with modality (cf. Quirk et al. 1985: §4.3, 4.42; Huddleston and Pullum 2002: 208-212). According to Huddleston and Pullum (2002: 209-210), the reason is three-fold, i.e. i. the presence of the preterite form would make the relationship between took and take exactly the same as would take and will take; ii. The syntactic behaviour of will as a modal auxiliary is exactly in the same fashion found in can, may, must, etc. The syntactic behaviours of those modal auxiliaries are known as NICE properties concerning, i.e. negation, inversion, code and emphasis, originally presented in Huddleston (1976). Emphasis is weakly observed, as demonstrated in (1); iii. The semantic content of will denotes an epistemically weaker version of the simple present tense, e.g. That is the doctor $\mathrm{v}$. That will be the doctor. The latter refers to the present time, but 
INTENTION IN FUTURITY: A HISTORICAL OBSERVATION OF THE FUTURE...

indicates less certainty. In addition to these, English lack the conjugational marking for the future tense, unlike its past tense counterpart, $-(e) d$.

(1) a. She will/can not go out in the evening. (negation)

b. Will/can she go out in the evening? (inversion)

c. She will/can go out in the evening, and so will he. (code)

d. ?She will/can go out in the evening. (emphasis)

Whatever the reason is, the auxiliary verbs will and shall can carry more than a tense marker, e.g. the epistemic reading from desire in will and the deontic reading from a sense of obligation in shall and therefore, they are considered as modal auxiliaries.

\section{History of futurity markers in English}

There are four different expressions to denote futurityin the history of English, i.e. weorðan 'become' (until the $15^{\text {th }} \mathrm{C}$ ), shall 'owe' (from $\mathrm{OE}$ onwards), willan 'want' (from the $16^{\text {th }} \mathrm{C}$ ) and be going to (from the $17^{\text {th }} \mathrm{C}$.).

Like other Germanic languages of the same period, Old English used an inchoative verb 'become', i.e. weorðan. In Modern German, for instance, its cognate werden 'become' still functions as a future tense marker (s.v. OED worth v. ${ }^{1} 3 \mathrm{a}, \mathrm{b}$ ). This verb in OE is polysemous, and there are several functions assigned to it. Apart from the futurity, it is often considered as an auxiliary for the passive voice or the passive voice cum future tense marker (Visser 1963-73: §1918; Mitchell 1985: §755; Kilpiö 1989: 61-62) as exemplified in (2). Note that its usage as the passive marker is highly doubtful, and it is more likely the case that it was a residue of earlier aspectual system inherited from Proto-Indo-European expressing resultative aspect and not the passive, or more precisely, it is the case of so-called secondary state, indicating a resulting state caused by outer cause (Nedjalkov and Jaxontov 1998: 4; Toyota 2008: 15-28). What is noticeable in the case of older English in comparison with other older Germanic languages is that in spite of its functional load, weorðan 'become' had been steadily in decline in use and it was nearly extinct by the end of the $16^{\text {th }}$ century (s.v. OED worth v. ${ }^{1}$ 2) and this still remains mystery in the history of English (Strang 1970: 351). Alongside weorðan 'become', a new 
verb with a similar basic meaning, become, appeared from the $12^{\text {th }}$ century (s.v. OED become II 5, 5b) but this verb has never been closely associated with futurity. Nevertheless, due to weorðan 'become' turning obsolete, it is unlikely that this verb was used as a productive future tense marker, but futurity was merely implied by its irrealis nature in lexical meaning, i.e. a state implied by 'become' is achieved in future and this irrealis-based futurity is what we find in 'become' used as a future tense marker in other modern Germanic languages. Thus, weorðan 'become' had hardly played an important role in forming the future tense in Old English, and its use as a future tense marker is quite negligible.

(2)

\begin{tabular}{|c|c|c|c|c|c|c|}
\hline $\begin{array}{l}\text { and behyddon } \\
\text { and hid } \\
\text { wurde } \\
\text { become.PST }\end{array}$ & $\begin{array}{l}\text { poet } \\
\text { the }\end{array}$ & $\begin{array}{l}\text { heafod } \\
\text { head }\end{array}$ & $\begin{array}{l}\text { paet } \\
\text { so.that }\end{array}$ & $\begin{array}{l}\text { hit } \\
\text { it }\end{array}$ & $\begin{array}{l}\text { bebyrget } \\
\text { bury.PST.PRT }\end{array}$ & $\begin{array}{l}n e \\
\text { NEG }\end{array}$ \\
\hline
\end{tabular}

Depending on the source of grammaticalisaiton, some forms retain partial original meanings, and this is the case in both shall and will. The original lexical meaning of shall is 'owe', and it is retained as deontic modality and this is still preserved in its use as a modal auxilairy, especially in the second and third person, but not in the first person. Thus, the first person form, I/we shall do, can be an unmarked for futurity, although there is a strong dialectal tendency and this usage is commonly found in Southern Standard British English and in addition, according to the traditional prescriptive grammar, British English has upheld the use of shall as the correct form, in preference to will, with a first person subject in formal style (Quirk et al. 1985: §4.42). The second and third person subject may denote futurity cum deontic modality, i.e. you/he/she shall do 'you/ he/she will have to do', e.g. "The usage as to the choice between the two auxiliaries has varied from time to time; since the middle of the 17 th c. the general rule (subject to various exceptions) has been that mere futurity is expressed in the first person by shall, in the second and third by will" (s.v. OED shall v. 8). Thus, shall is indeed a future tense marker, but at the same time defective in terms of markedness in its semantics, i.e. "sceal (shall) even when rendering a Latin future, can hardly be said to have been ever a mere tense-sign in OE.; it always expressed something of its original 
notion of obligation or necessity" (s.v. OED shall v. 8). English has not really fixed this defectiveness and this can be a reason for its decline in use. However, in relation to this defective system, there seems to be some other causes for decline.

The first point, often not noticed, is politeness. The decline of shall is perhaps related to the surge of awareness of courtesy to others in verbal interactions, as also found elsewhere in grammar especially after the reign of Richard II, who introduced different aspects of French culture at that time to England (Toyota 2011). The Anglo-Saxon society had a hierarchical system, with the King at the top and the feudal system introduced after the Norman Conquest also extended social hierarchy. However, it was Richard II that really made this system verbally more obvious, by introducing terms of address such as Your Majesty, and forcing people to bow their knees when addressing to someone higher in the hierarchy. This type of practice made people weary about how to address to others. This awareness enriched linguistic expressions and a general trend was to avoid being rude, rather than to be polite. For instance, the loss of the thou-ye distinction in the second person pronouns was triggered by this awareness, and it took place by around the $15^{\text {th }}$ century and the surge of the passive voice to avoid the mention of a doer of action is in part ascribed to the issue of politeness, too, although the passive voice was not grammaticalised until around the late $17^{\text {th }}$ century (cf. Toyota 2005, 2008).

Another reason can be that the Latin translation often induced the use of shall, not will, and perhaps it was the case that shall was contextually associated with a certain genre of texts, such as religious text. This type of restriction in use indeed forced shall out of context in the common daily language. However, it was the introduction of Christianity that spread education in the Anglo-Saxon England and without it, it would have been more difficult for shall to grammaticalise into the future tense marker.

Concerningwill, its origin is an OE/ME verb willan 'want'. It used to take a noun as well as another verb as its object. The example (3) and (4) are both taken from Old English, and (3)is an example with a nominal direct object and (4) with a verbal direct object. The example (5) contains both cases, e.g. the first instance of willan 'want, desire' takes the nouns (e.g. castles and kinedomes 'kingdom') as its object, and the second instance, a verb (e.g. wealden 'rule'). The nouns ceased to be a direct object 
for willan by the end of Middle English. By this time, its semantic range is restricted to reference to futurity and meanings of 'want, desire' were lost. A further ongoing change is found in its phonological reduction, since now will can be shortened as -' $l l$ as in I' $l l$. This form is predominantly used with the pronouns in Present-Day English and it has to go further to be used with other nouns, but its development is currently ongoing. This development and its chronology are schematically illustrated in Figure 1. Note that changes are gradual process and there is a considerable overlap between overlapping stages. This is shown by the dotted lines in the figure.

\section{Old English}

(3)

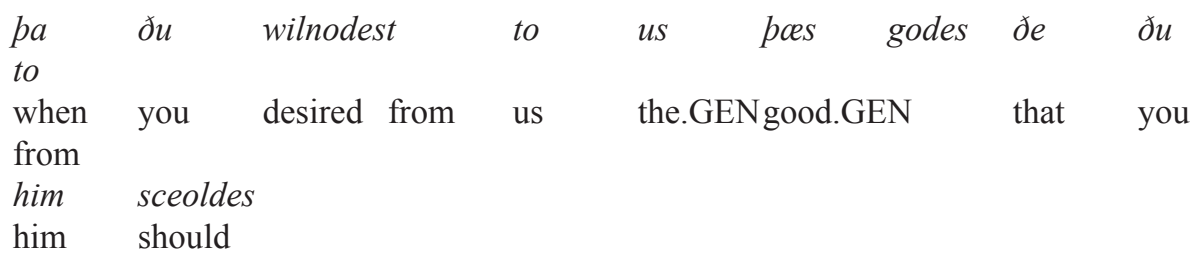

'When you desired from you the good that you should fro him.' (Bo 19.15)

\section{Old English}

$\begin{array}{llllll}\text { wen } & \text { is } & \text { poet } & h i & \text { us lifigende öungre wyllen sniome } \\ \text { expectation } & \text { is } & \text { that } & \text { they } & \text { us living quickly intend at.once }\end{array}$
forsweolgan swallow

'It is likely that they will/want to swallow us up at once.' (PPS 123.2)

(5)

\section{Middle English}

wult tu castles. kinedomes. wult $u$ wealden al
world?
want you castles kingdoms want you rule all the
world
'Do you want castles, kingdoms? Do you want to rule the whole world?' (c1230(?a1200)
Ancr. 107b.25)


INTENTION IN FUTURITY: A HISTORICAL OBSERVATION OF THE FUTURE...

\begin{tabular}{|c|c|c|c|c|c|}
\hline $\mathrm{OE}$ & & & eModE & 1ModE & PDE \\
\hline \multicolumn{2}{|r|}{1100} & 1500 & & 1750 & \\
\hline \multicolumn{6}{|c|}{ Lexical verb } \\
\hline \multicolumn{6}{|c|}{ Modal auxiliary } \\
\hline & & \multicolumn{4}{|c|}{ Suffix -'ll } \\
\hline
\end{tabular}

Figure 1. Schematic representation of grammaticalisation of English will

English has also created yet another phrase referring to the future based on the motion verb, i.e. be going to. The earliest attested example is from the late $15^{\text {th }}$ century (cf. (6)), but it seems an isolated case. The frequency seems to be increased after the $18^{\text {th }}$ century (s.v. OED go v. 47b), e.g. (7) and (8). One of the motivations for a language to acquire a new future tense is through what Heine and Kuteva (2005) terms replication. This is a contact-induced grammaticalisation, but a target language initiates a whole process instigated by a contact with a source language, and unlike a simple borrowing, a target language uses its own resource to create a new form. Future tense is one of the grammatical structures that are likely to be replicated, along with evidential or relative pronouns (Heine and Kuteva 2003: 265), and the English be going to is a case of replication after a contact with the Norman French, which has a near future (future prochain) based on a motion verb aller 'go'. A simple borrowing would have resulted in English using a French tense marker, e.g. *I vais/ve go for 'I will go', but this is not what happened. Romance languages except Romanian utilise a typologically rather rare grammaticalisation path based on verbs of possession, and this was not replicated into English, but a typologically common type, i.e. a motion verb 'go' was. Toyota (2012) argued that this is due to the gap between human cognitive ability and the lack of a specific linguistic form, i.e. people can talk about future but some languages lack a specific tense form. This discrepancy encourages speakers without a future tense to replicate a future tense. 
(6)

Thys onhappy sowle..was goyng to be broughte into helle for the synne and onleful lustys of her body. (1482Monk of Evesham (Arb.) 43)

(7)

I believe next news I heare will be that you are going to bee married. (1672 LADY M. BERTIE in 12th Rep. Hist. MSS. Comm. App. v. 26)

As I was going to say. (1703LOCKELet. 23 July (On Dr. Pococke))

A verb of desire will 'want' eventually has won the competition and it is now most commonly used along with be going to, although the latter is most closely associated with the near future. Another option, shall, which may be somewhat obsolete now, implies futurity cum a sense of deontic modality, obligation. In the history of English, Both will (OE willan 'wish, desire') and shall (OE sceall 'owe') existed in Old English as a marker for futurity, along with weorðan 'become'. The motion verb go as a future tense marker in the phrase be going to is added to the other choices from ca. the $18^{\text {th }}$ century (s.v. OED go v.47.b). The chronology is schematically summarised in Figure 2. The dotted line represents that the form was present, but not frequently used, i.e. either decline or increase in frequency.

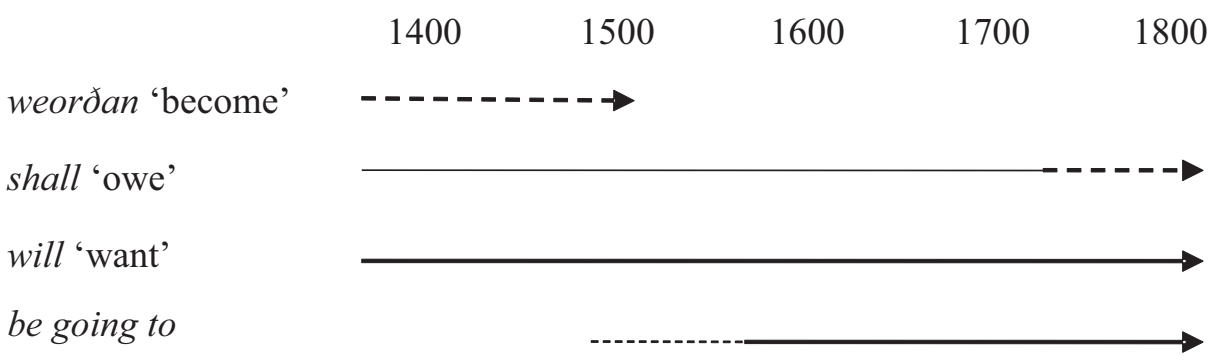

Figure 2. Diachrony of markers of futurity

\section{Grammaticalisation and emergence of future tense}

When it comes to the diversity of future tense and historical development, there are several grammaticalisation paths of the future tense. Some are more common and others rarer. Heine and Kuteva (2002) presents motion verbs, modality and verbs of desire are typologically common devel- 
opmental paths. Interestingly, English has covered all of these common paths along with an inchoative verb 'become'. However, these changes occurred at different periods and some co-existed. In this section onwards, we restrict our argument to two auxiliaries, will and shall, since they have reached farther stage (i.e. cliticisation) in grmmaticalisation.

From a perspective of historical linguistics, especially grammaticalisation, auxiliaries are an intermediate stage between a lexical item and a grammatical one such as an affix (cf. Heine et al. 1991). This makes a description of tense system in some language very difficult. Considering the other Indo-European languages, the future tense is often expressed with a suffix, as in the case of French, e.g. the suffix -ai in je retourner-ai 'I will return'. In such languages, the tense system can be clearly considered as a ternary one, i.e. past v. present v. future. The relationship between the grammaticalisation path and the presence/absence of future tense is illustrated in Figure 3. According to this line of historical development, the Englishtense system seems to have been developing into the past $\mathrm{v}$. present $v$. future type, but its process has not reached the stage of affix. Some instances may behave like the fully-fledged future tense, but those sporadic instances are perhaps the reason why some claim that there is a future tense in English. When the tense system is considered synchronically, the ongoing development is overlooked. In English, a hint of development further from modal auxiliaries is found in -' $l l$, a clitic form of will and shall as in I'll go there tomorrow. This is still optional, but according to the general direction of changes shown in Figure 3, it is possible that the future tense in English may be expressed in terms of conjugation, after the clitic being firmly established and turning into an affix or a tense marker. Thus, as marked in Figure 3, the ternary tense distinction is only possible after the stage of clitic.

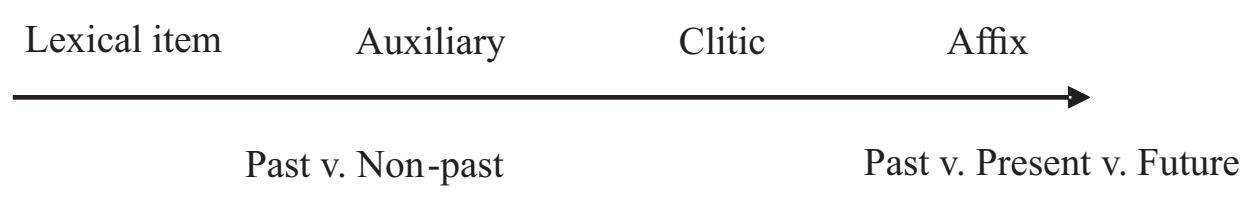

Figure 3. Gradualness in grammaticalisation of future tense

What is not overtly shown in Figure 3 is semantic changes involved in grammaticalisation. What is commonly observed in the course of the 
historical development is the loss of volition or intentionality (see, among others, Bybee et al. 1991; Ziegler 2006; Hilpert 2008).In the case of PDE, the distinction in person is closely related to the presence/absence of intentionality, e.g. the development of both will and shall express intension with the first and second person subject, e.g. in making agreements, promises, threats, etc., e.g. (9) and (10), and with a second and third person subject, willcan also express an abrupt and quasi-military command, expressing the intension or desire of the first person, e.g. (11) (Quirk et al. 1985: $\S 4.41,4.42)$. These patterns suggest that the first person and possible also second person potentially express intension when referring to futurity, as summarised in Figure 4. The darker shade indicates a higher degree of likelihood to observe intentionality.

\section{(8)}

We shall/will ensure that the repairs are carried out according to your wishes.

How soon will you announce your decision?

(10)

Officers will report for duty at 0600 hours.

\begin{tabular}{|l|c|c|}
\cline { 2 - 3 } \multicolumn{1}{c|}{} & SG & PL \\
\hline 1sr person & & \\
\hline $2^{\text {nd }}$ person & & \\
\hline $3^{\text {rd }}$ person & & \\
\hline
\end{tabular}

\section{Natural occurrence of clitic form}

Concerning the clitic -' $l l$, it can be in theory attached to any noun phrases. However, the corpus data show that there is a strong tendency for the clitic to appear with personal pronouns. Table 1 shows the result of the data from the London-Lund corpus (LL corpus, spoken) and LondonOslo-Bergen corpus (LOB corpus, written), and the clitic appears with the personal pronouns in nearly 90 percent of the occurrence. Furthermore, 
the clitic is most commonly used with the first person pronoun among these personal pronouns, as Table 2 shows. The examples shown in (12) to (15) are rare examples, where the subject is common nouns (indicated as others in Table 1). The distribution among the personal pronouns may not be as striking as the one for the general frequency of the clitic, but the dominance of the first person is obvious.

Table 1. Frequency of clitic forms - ' $l l$

\begin{tabular}{|c|c|c|c|c|c|}
\hline & $\begin{array}{l}\text { Personal } \\
\text { pronouns }\end{array}$ & $\begin{array}{l}\text { Inanimate } \\
\text { pronouns }\end{array}$ & $\begin{array}{c}\text { Indexical/ } \\
\text { interroga- } \\
\text { tive pro- } \\
\text { nouns }\end{array}$ & Others & Total \\
\hline Spoken & $816(84.0 \%)$ & $77(7.9 \%)$ & $63(6.5 \%)$ & $15(1.6 \%)$ & $971(100 \%)$ \\
\hline Written & $468(93.2 \%)$ & $16(3.2 \%)$ & $14(2.8 \%)$ & $4(0.8 \%)$ & $502(100 \%)$ \\
\hline Total & $\begin{array}{llll}1 & 2 & 8 & 4 \\
(87.2 \%) & \end{array}$ & $93(6.3 \%)$ & $77(5.2 \%)$ & $19(1.3 \%)$ & $\begin{array}{lccc}1 & 4 & 7 & 3 \\
(100 \%) & \end{array}$ \\
\hline
\end{tabular}

Table 2. Frequency of clitic forms -' $l l$ with personal pronouns

\begin{tabular}{l|l|l|l|l}
\hline & $1^{\text {st }}$ person & $2^{\text {nd }}$ person & $3^{\text {rd }}$ person & Total \\
\hline Spoken & $566(69.4 \%)$ & $126(15.4 \%)$ & $124(15.2 \%)$ & $816(100 \%)$ \\
\hline Written & $276(59.0 \%)$ & $122(26.0 \%)$ & $70(15.0 \%)$ & $468(100 \%)$ \\
\hline Total & $842(65.6 \%)$ & $248(19.3 \%)$ & $194(15.1 \%)$ & $1284(100 \%)$ \\
\hline
\end{tabular}

(11)

... by the time you get it, the money'll be so much devalued. (LLC 02)

thereafter, the results'll becarefully analysed. (LLC 11)

(13)

Perhaps the fishes'll grow as strong and virile as the Shoshone Indians. (LOB K08 89-90)

(14)

Miss Jeannie'll be on that coach, Dan. (LOB N06 81)

The data shown in Table 1 and Table 2 can be a result of phonological easiness in pronouncing the sequence of the personal pronouns and the 
clitic, e.g. it is much easier to pronounce the sequence with persona pronouns, such as I'll, you'll, we'll, etc. in comparison with common nouns, i.e. (12) to (15). However, apart from this phonological factor, the high frequency of the first person pronouns (cf. Table 2) should be considered in relation to the presence of intentionality. The first person pronounsis heavily influenced by epistemic or deontic modality, but what is crucial here is the influence from knowledge or evaluation of events or states of affairs, and although modality may be deontic, knowing the existence of necessity or obligation is crucial in this case. Since the grammaticalisation path of will and shallhas not been fully complete, it is natural that epistemic modality is still visible. This is also related to the presence of intentionality, i.e. the clitic form is more visible when intentionality is associated with will or shall (cf. Figure 4).

Another issue concerning this relationship is the range of futurity. Future tense can be divided into near future, distant future, etc. French, for instance, has general future expressed by the conjugation, and near future by the use of a motion verb aller 'go'. A type of futurity created by the clitic in English can be considered as near future, not general future. The doer of action denoted by a clause with the clitic is most likely a speaker him/herself, and in addition, speaker's intention can be detected in this case. Thus, likelihood of events in future is more easily knowable to him/her. Under these conditions, the futurity is unlikely to be general future.

It seems that the form itself is one step closer to the future tense once the clitic is used (cf. Figure 3), but the clitic itself may not be as grammaticaliased as once assumed. The loss of intentionality is commonly believed to have happened in forming auxiliary, but in case of English, it is bound to happen when the clitic use is spread to nouns other than personal pronouns. This is when the clitic is fully grammaticalised as the future tense marker.

\section{Summary}

Future tense is not yet fully developed in English, but various factors including contact-induced changes provide much possibility for English to develop a specific future tense form. Judging from the grammaticalisation chain, the presence of the clitic form is a good indicator that the fully-fledged future tense may appear soon. Currently, the clitic form is restricted to personal pronouns, especially the first person pronouns. This 
close relationship between the clitic -' $l l$ and the first person pronouns is considered as a result of expressing intentionality regarding future, and this will be a base for creating a fully-fledged future tense in English. Since the intention refers to a certain point in future, futurity expressed with the clitic does not refers togeneral future, but to near future.

The current usage is highly restricted to the personal pronouns, particularly the first person pronouns, and one may be able to claim that the future tense is defective. The second and third person pronouns are not yet so commonly used and this is perhaps the next stage towards the full grammaticalisation. This is simply the beginning and synchronic analysis may not yield much insight, but diachronic analysis, although it is at its beginning, can shed light on possibility for future changes.

\section{References}

Bybee, J., W. Pagliuca and R. Perkins (1991). 'Back to the future.'In E. C. Traugott and B. Heine (eds.) Approaches to Grammaticalization (Vol. 2). Amsterdam: John Benjamins, 17-58.

Heine, B., U. Claudi and F. Hünnemeyer (1991). Grammaticalization: a conceptual framework. Chicago: University of Chicago Press.

Heine, B. and T. Kuteva (2002). World Lexicon of Grammaticalization. Cambridge: Cambridge University Press.

Heine, B. and T. Kuteva (2003). 'On contact-induced grammaticalisation.' Studies in Language 27, 529-572.

Heine, B. and T. Kuteva (2005). Language Contact and Grammatical Change. Cambridge: Cambridge University Press.

Hilpert, M.(2008).Germanic Future Constructions: A usage-based approach to language change. Amsterdam: John Benjamins.

Huddleston, R. D. (1976). 'Some theoretical issues in the description of the English verb' (review of The English Verb, by F. R. Palmer). Lingua 40, 331-383.

Huddleston, R. D. and G. K. Pullum (2002). The Cambridge Grammar of the English Language. Cambridge: CambridgeUniversity Press.

Kilpiö, M (1989): Passive Constructions in Old English Translations from Latin: with Special Reference to the OE Bede and the 'Pastoral Care'. Helsink: Societe Neophiloologique. 
Mitchell, B. (1985).Old English Syntax (2 vols). Oxford: Clarendon Press.

Nedjalkov, V. P. and S. J. Jaxontov (1988).'The typology of resultative constructions'. In Nedjalkov, V. P. (ed.): Typology of Resultative Constructions. Amsterdam: John Benjamins, 3-62.

$O E D=$ Simpson, J. A. and E.S.C. Weiner (1989).The Oxford English Dictionary ( $2^{\text {nd }}$ ed.). Oxford: Clarendon Press.

Quirk, R., S. Greenbaum, G. Leech and J. Svartvik (1985).A Comprehensive Grammar of the English Language.London: Longman.

Strang, B. (1970).A History of English. London: Methuen \& Co. Ltd.

Toyota, J. (2005). 'Politeness as a distancing device in the passive and in indefinite pronouns.' In Skaffari, J., M. Peikola, R. Carroll, R. Hiltunen and B. Wårvik (eds.): Opening Windows on Texts and Discourses of the Past. Amsterdam: John Benjamins, 319-339.

Toyota, J. (2008). Diachronic changes in the English passive. Basingstoke: Palgrave.

Toyota, J.(2011). 'Richard II: his hidden legacy in the English language.' Belgrade English language and literature studies 3, 9-32.

Visser, F. Th. (1963-73).An Historical Syntax of the English Language(4 vols.). Leiden: E. J. Brill.

Ziegeler, D.(2006). Interfaces with English Aspect: Diachronic and empirical studies. Amsterdam: John Benjamins.

Đunići Tojota

Sažetak

\section{NAMERA U BUDUĆNOSTI: ISTORIJSKO RAZMATRANJE BUDUĆEG VREMENA U ENGLESKOM JEZIKU}

U radu se analiziraju različiti izrazi koji se odnose na budućnost u engleskom jeziku, iz istorijske perspektive. Poznato je da engleski nema buduće vreme, ali se budućnost izražava deontičkom ili epistemičkom modalnošću sa shall i will. Prema opštem principu gramatikalizacije, pomoćni glagoli se smatraju jednim stadijumom pre nego što leksička jedinica postane afiks. Tokom ovog procesa dešava se gubljenje semantičkog sadržaja, odnosno semantičko izbeljivanje. Smatra se da se gubljenje intencionalnosti desilo pri formiranju pomoćnog glagola. Međutim, ispravnije je tvrditi da se ona ipak zadržala, a da se semantičko izbeljivanje dešava u nešto kasnijoj fazi, u procesu klitikalizacije (produkcije -'ll), koja se trenutno deogađa u engleskom jeziku. $\mathrm{Na}$ osnovu trenutnog stanja gramatikalizacije moguće je pretpostaviti šta će se dalje dešavati sa sistemom vremena u engleskom. 